電磁アクチュエータ一体型マイクロリニアポンプ

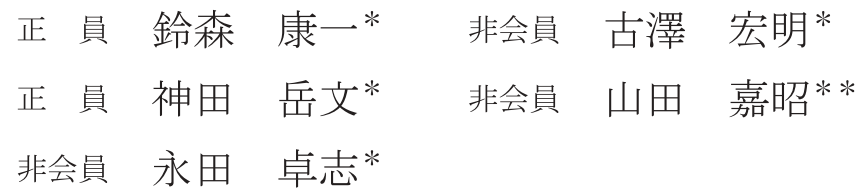

\title{
Micro Linear Pump with Electromagnetic Actuator
}

Koichi Suzumori*, Member, Hiroaki Furusawa*, Non-member, Takefumi Kanda*, Member, Yoshiaki Yamada**, Non-member, Takashi Nagata*, Non-member

In recent years, research and development of the micro-fluid systems have been activated in the field of chemical technology and biotechnology. Micro-fluid systems are realized by micromachine technology and MEMS technology. Micro pump is an essential element for miniaturization of chemical analysis reaction systems. The aim of this research is development of a micro linear pump which will be built into micro-fluid systems. This pump aims to take a sample of very-small-quantity of liquids. Taking a sample of very-small-quantity of liquids reduce the amount used and waste fluid of a reagent. Full length and diameter of this pump are $32.5 \mathrm{~mm}$ and $6 \mathrm{~mm}$ respectively. The features of this pump are (1) the pump is built with actuator, (2) the gap of $7 \mu \mathrm{m}$ between piston and cylinder is achieved through fine machining process, and (3) micro check-valves of $2 \mathrm{~mm}$ diameter made of stainless-steel film are fabricated and integrated. In this paper, the structure and the characteristics of this pump were shown. And the characteristics after improvement of micro check-valves were shown.

キーワード : マイクロ流体システム, マイクロリニアポンプ, 微量サンプリング, アクチュエーター体型, 小型化

Keywords : micro-fluid system, micro linear pump, sample of very-small-quantity, built-in actuator, miniaturization

\section{1. まえがき}

近年，マイクロリアクタ， $\mu \mathrm{TAS}$, Lab-on-Chip 等, マ イクロ流体システムの研究が活発に進められている。この ようなマイクロ流体システム実現の要となる要素の一つは マイクロポンプである。

従来, チップ上に集積されるマイクロポンプとして, MEMS 技術を利用して作られる圧電素子駆動のダイヤフラ ム型のポンプを始め, 様々なマイクロポンプが開発されて きた(1)。これらのポンプはマイクロ化や集積化に適してお り, 数 $\mathrm{nl} / \mathrm{min}$ から数 $100 \mathrm{nl} / \mathrm{min}$ 程度の微小流量制御を対象 に開発されている。

一方で, 数〜数 $10 \mathrm{ml} / \mathrm{min}$ オーダの吐出量を持ち, チップ の外付けで利用される自立型のマイクロポンプのニーズも

* 岡山大学大学院自然科学研究科

$\bar{T} 700-8530$ 岡山県岡山市津島中 3-1-1

Okayama University

3-1-1, Tsushima-naka, Okayama 700-8530

$* *$ 岡山県産業振興財団

=701-1221 岡山県岡山市芳賀 5301

Industrial Promotion Foundation of Okayama Prefecture 5301 Haga, Okayama 701-1221
高まっている。

このようなマイクロポンプとして, マイクロギヤポンプ やマイクロトロコイドポンプ(2), 圧電素子を用いたダイヤフ ラム式マイクロポンプ(3)等が開発されているが, いずれもポ ンプ全体の体積に対する吐出量の割合が低い。マイクロギ ヤポンプやマイクロトロコイドポンプは, 機械的エネルギ 損失が比較的大きく，外部に比較的大きなアクチュエータ を必要とし，小型化をする上で問題となっている。また， ダイヤフラム式マイクロポンプは一般に駆動電圧が高い 上, 吐出量/ポンプ体積比も優れているとはいえない。チッ プへの組込みの際には, 吐出量/ポンプ体積比の高いポンプ が望まれている。

本研究では, 数 $\mathrm{ml} / \mathrm{min}$ 程度の吐出量を持ち, 吐出量/ポ ンプ体積比の優れたマイクロポンプの実現を目標とし, 電 磁アクチュエータと一体となったマイクロリニアポンプの 開発を行なった。

\section{2. マイクロリニアポンプの設計}

〈2·1〉構造と駆動原理図 1 に試作した全長 $32.5 \mathrm{~mm}$, 直径 $6 \mathrm{~mm}$ のマイクロリニアポンプの外観を示す。 


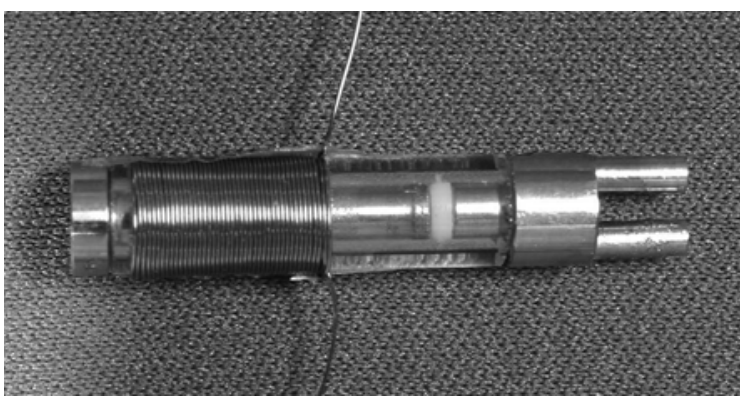

図 1 マイクロリニアポンプ

Fig. 1. Micro linear pump.

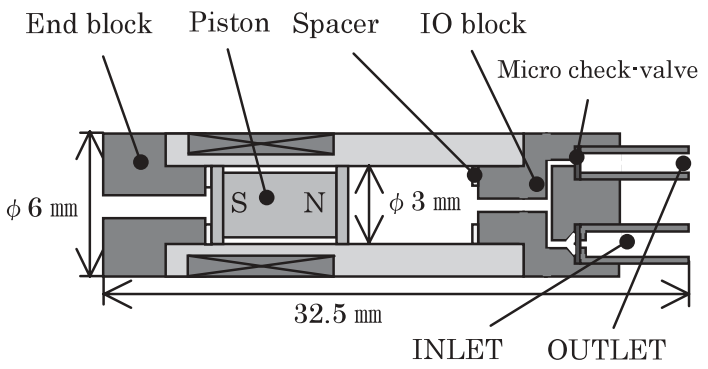

図 2 マイクロリニアポンプの構造図

Fig. 2. Structure of micro linear pump.

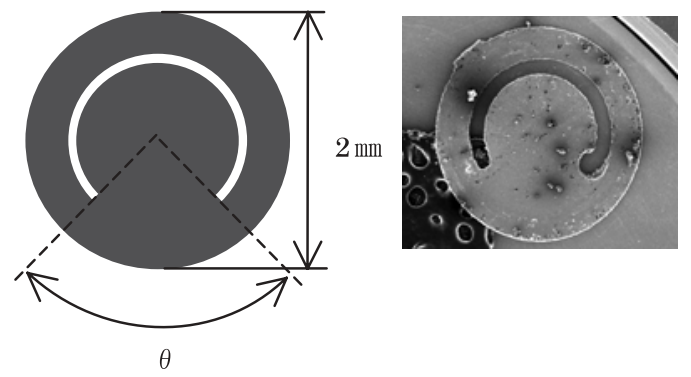

図 3 マイクロリニアポンプの IO ブロック内に 取り付けられたマイクロチェックバルブ

Fig. 3. Micro check-valve in IO block of micro linear pump.

図 2 に示すように, 外周に線径 $0.2 \mathrm{~mm}, 200$ 巻のコイルが 形成された石英ガラス製のシリンダ内を全長 $9 \mathrm{~mm}$, 直径 $3 \mathrm{~mm}$ のサマリウムコバルト永久磁石製のピストンが往復運 動する構造となっている。精密旋盤による微細加工により, ピストンの直径とシリンダの内径との径の差を平均 $7 \mu \mathrm{m}$ で 仕上げられている。また, ピストンが往復運動する際の衝 撃を吸収するためにクッション性のあるテフロン製のスペ 一サがピストンの前方と後方に設けられている。ピストン のストロークは $5 \mathrm{~mm}$ である。このマイクロリニアポンプ は, 構造の簡略化を目的としており, 強磁性材料を用いた 磁路回路を持たない構造とした。

このマイクロリニアポンプの構造的特徵として, 外部に 他のアクチュエータを必要とせず, 構造が簡単であるので, 大きな吐出量/ポンプ体積比が得られ, 小型化と量産化を行 ないやすい点が挙げられる。

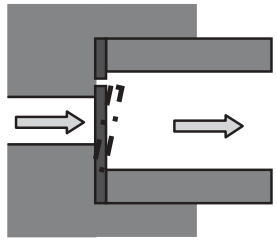

OUTLET

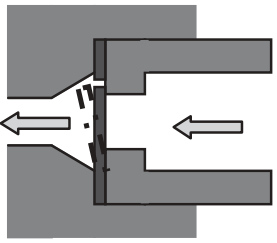

INLET
図4 マイクロリニアポンプの IO ブロック内に あるマイクロチェックバルブの動作

Fig. 4. Operation of micro check-valve in IO block of micro linear pump when fluid is flowing.

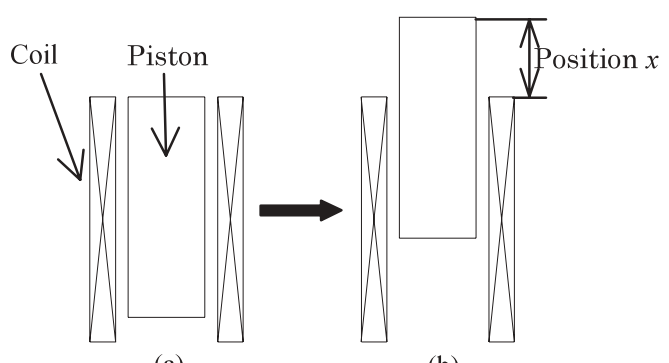

(b)

図 5 磁場解析時におけるコイルに電圧を印加した 時のピストンの動作

Fig. 5. Operation of piston when voltage is applied to a coil at the time of magnetic field analysis.

〈2·2〉 マイクロチェックバルブＩO ブロック内には 流体の方向制御のために図 3 に示寸厚さ $0.02 \mathrm{~mm}$ のステン レス薄膜で作られた直径 $2 \mathrm{~mm}$ のマイクロチェックバルブ が吸入口と吐出口に付けられている。今回, バルブの耐久 性と動作を考慮して，片持ち部の幅を示寸図 3 中の $\theta$ が $105^{\circ}$ のものと $30^{\circ}$ のものの 2 種類のマイクロチェックバ ルブを製作し，比較検討を行なった。

吸入時と吐出時のマイクロチェックバルブの動作の様子 を図 4 に示す。このマイクロチェックバルブは流体から力 を受けることによって受動的に動作する。

$\langle 2 \cdot 3\rangle$ 磁路設計 有限要素法を用いて磁場解析を行 い,コイルとピストンの位置と大きさの最適設計を行った。 図 5(a)に示すように，ピストンとコイルの端面が揃った位 置を 0 として, 図 5(b)に示すようにピストンの位置を $x$ で 表すことにする。

ここでは, ピストンの動作ストロークを $5 \mathrm{~mm}$, 動作に要 する吸引力を $0.03 \mathrm{~N}$ と設定して設計を進めた。ピストンが 安定して動作するには，ピストンの動作範囲のどの位置に おいても，上下どちら方向にも目標とする大きさの吸引力 を発生させる必要があり, コイルやピストンの大きさを変 えて設計を行った。設計結果を以下に記す。

図 5 に示すように, ピストンの位置を変えて, ピストン の位置 $x$ とピストンがコイルから受ける吸引力の関係を解 


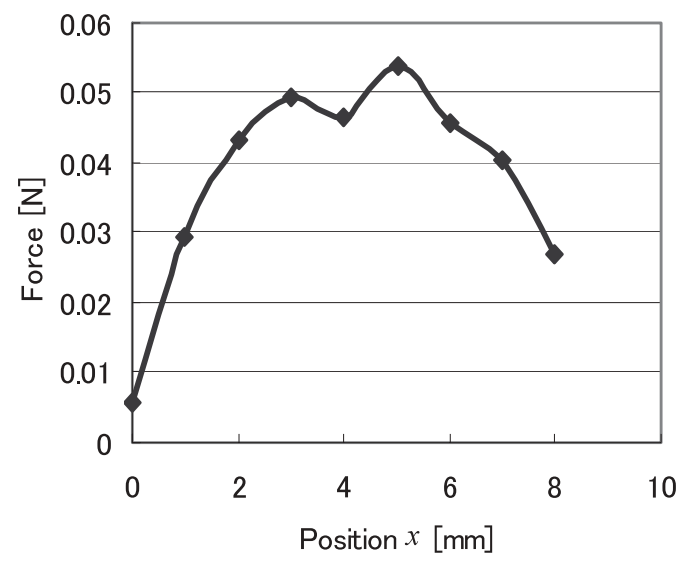

図 $6500 \mathrm{~mA}$ 駆動時におけるコイルが発生する 吸引力の磁場解析による計算結果

Fig. 6. Calculated results of coil suction force at the driving current of $500 \mathrm{~mA}$ by magnetic field analysis.

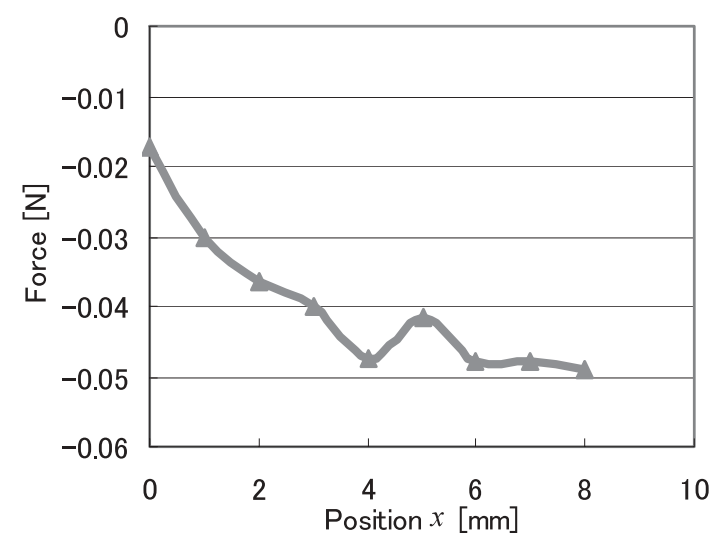

図 $7-500 \mathrm{~mA}$ 駆動時におけるコイルが発生する吸引力 の磁場解析による計算結果

Fig. 7. Calculated results of coil suction force at the driving current of $-500 \mathrm{~mA}$ by magnetic field analysis.

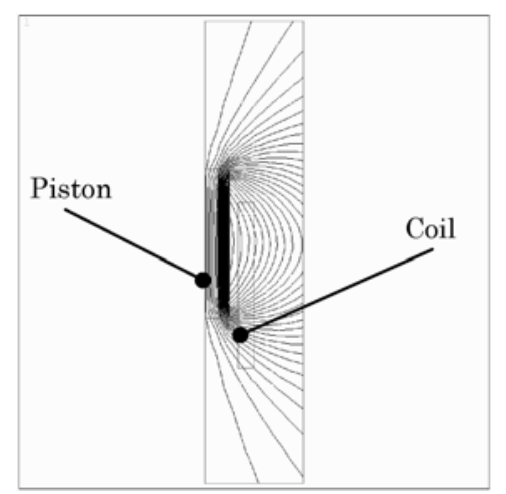

図 8 磁場解析により得られた磁束線図

Fig. 8. Lines of magnetic flux by magnetic field analysis.
析した。図 5 の上方向へかかる力を正とする。解析ではコ イルを 200 巻, 電流を $\pm 500 \mathrm{~mA}$ と想定した状態で磁場解析 をそれぞれ行なった。解析により得られたコイルの吸引力 を図 6 と図 7 に示す。また, 図 8 に解析により得られた磁 束線図を示す。

ここでは図 6 と図 7 からピストンの位置 $x$ が $2 \mathrm{~mm}$ 以下 7 $\mathrm{mm}$ 以上ではコイルの吸引力が小さく流水時に力が不足す ると考えられるが， $x$ が $2 \sim 7 \mathrm{~mm}$ 上方の範囲では上下どち ら方向にも常に $0.03 \mathrm{~N}$ 以上の吸引力が得られており, この 範囲でピストンは安定した動作が行える。

\section{3. 特性試験}

〈3.1〉 周波数追従特性 非流水時におけるピストン の周波数追従性の測定を行なった。ピストンが $5 \mathrm{~mm}$ の全ス トロークを完全に往復している状態を追従しているとし, 各電圧において周波数を $1 \mathrm{~Hz}$ から徐々に上げていきながら ピストンが追従する周波数の限界を測定した。測定ではピ ストンを駆動できる最低電圧の $0.4 \mathrm{Vp}-\mathrm{p}$ から $0.1 \mathrm{Vp}-\mathrm{p}$ ずつ 上げていき, 10 箇所の電圧值において測定した。測定によ り得られた結果を図 9 に示す。図 9 より電圧が上がるにつ れてピストンの追従する周波数の限界值はほぼ線形的に上 がっていき, 磁気飽和は認められない。また, コイルを指 で触った場合, コイルの温度は多少上昇しているが, 過度 の温度上昇は認められない。よって, 良好なアクチュエー 夕設計が実現できていることが確認できる。

〈3・2〉 周波数 - 吐出量特性 コイルに印加する電圧 の周波数と吐出量との関係を測定した結果を図 10 に示す。 なお，ここから〈3・4〉節までは， $\theta=105^{\circ}$ マイクロチェッ クバルブを用いた場合について説明する。

マイクロリニアポンプを各電圧, 各周波数で 3 分間駆動 し, 吐出された水の質量を量り 1 分間の吐出量を求める。 この作業を 3 回繰り返して得られたデータの平均值を図 10 に示している。図 10 よりどの電圧においてもある周波数ま

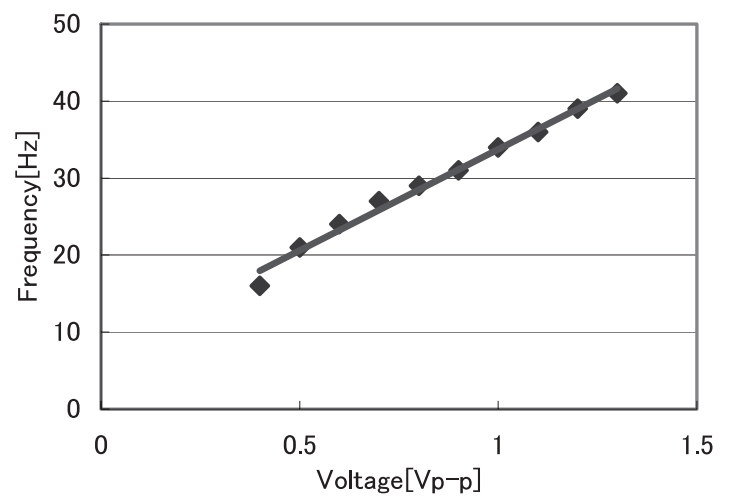

図 9 コイルに印加する電圧とピストンが追従する周波 数の限界値との関係

Fig. 9. Relation between applied voltage and limit value of frequency that piston follows. 


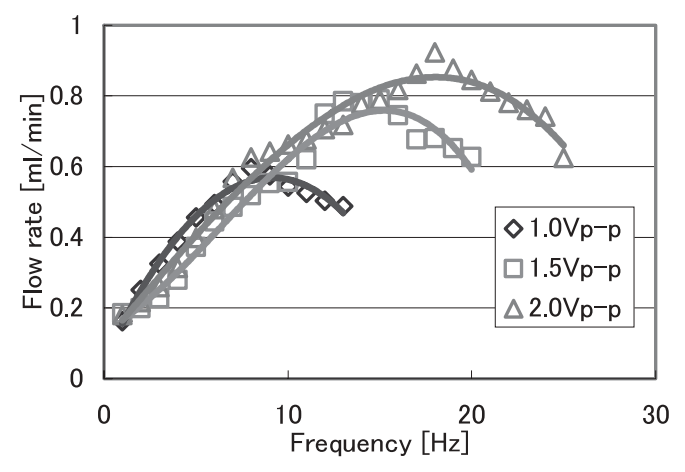

図 10 周波数と吐出量との関係

Fig. 10. Relation between frequency and flow rate.

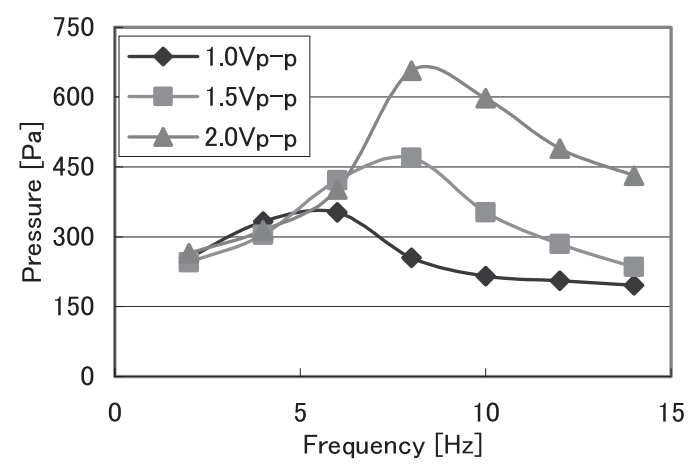

図 11 周波数と吐出圧との関係

Fig. 11. Relation between frequency and flow pressure.

では周波数が高くなるにつれて吐出量は増加し，それ以降 は減少していくという傾向が得られた。ピストンが追従で きなくなる周波数の限界值に達すると，ピストンの動作ス トロークが小さくなり, 吐出量が減少する。1.0Vp-p を例に 取ると，ピストンは $8 \mathrm{~Hz}$ 付近から $5 \mathrm{~mm}$ の全ストロークを 往復できなくなり, 非流水時に比べてピストンの追従する 周波数の限界值は $1 / 3 \sim 1 / 4$ になっている。

$\langle 3 \cdot 3\rangle$ 周波数 - 吐出圧特性 コイルに印加する電圧 の周波数と吐出圧との関係を測定した結果を図 11 に示す。 吐出口に取り付けたチューブを垂直に立て, マイクロリニ アポンプを各電圧，各周波数で 5 分間駆動させることによ りチューブ内の水面を安定させ水面の高さを測定する。こ こでいう水面の高さとは，吸入口側タンクの水面から吐出 口に取り付けたチューブ内の水面までの高さを意味する。 吐出圧は以下の式を用いて測定した水面の高さから計算し た。

$$
P_{D}=\rho \times g \times h
$$

ただし, 吐出圧を $P_{D}[\mathrm{~Pa}]$, 水の密度を $\rho\left[\mathrm{kg} / \mathrm{m}^{3}\right]$, 重力加速 度を $g\left[\mathrm{~m} / \mathrm{s}^{2}\right]$, 水面の高さを $h[\mathrm{~m}]$ とする。

図 11 より, 低い周波数域では電圧が異なっていても吐出

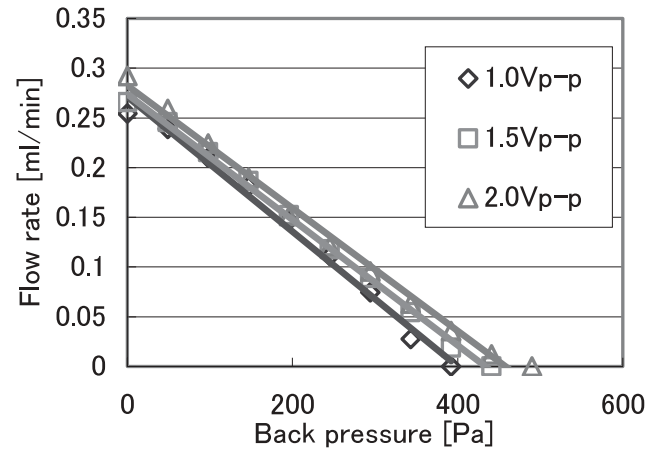

図 12 負荷圧力と吐出量との関係

Fig. 12. Relation between back pressure and flow rate.

圧はほぼ同じ值を示し, 周波数が高くなるにつれて吐出圧 は高くなっていくことがわかる。また高い周波数域では周 波数が高くなるにつれて吐出圧は低くなり, 電圧が高いほ ど吐出圧は高いこともわかる。

これは次のように説明できる。吐出側の圧力を $p_{o}$, 吸入 側の圧力を $p_{i}$ とする。一般に吐出側の圧力が高くなってゆ くと, チェックバルブの隙間やピストンとシリンダの隙間 を通って流体が吐出側から吸入側に流れようとする作用(こ れを逆流作用と呼び, この作用によって発生する流量を逆 流量と呼ぶ)が働く。逆流量は $p_{o}-p_{i}$ に比例するが, ポンプ が定常状態で動作している状態では, 無負荷時の吐出量(図 10) と逆流量は等しくなりバランスしている。

ピストンが追従する比較的低い周波数領域では, 図 10 に 示すように無負荷時の吐出量はコイルの印加電圧に依存せ ず, 周波数にほぼ比例する。従って逆流量および吐出側と 吸入側の差圧 $p_{o}-p_{i}$ も印加電圧には依存せず周波数のみに 依存する。

これに対して, 比較的高い周波数で, ピストンが追従し てこない領域では, 図 10 に示すように, 電圧を上げるほど 無負荷時の吐出量が増大し, 周波数に対して上に凸の曲線 を描くようになる。従って逆流量および吐出側と吸入側の 差圧 $p_{o}-p_{i}$ も電圧に依存し, 周波数に対して上に凸の曲線を 描

$\langle 3 \cdot 4\rangle$ 負荷圧力 - 吐出量特性 負荷圧力と吐出量と の関係を測定した結果を図 12 に示す。吸入口と吐出口に取 り付けたチューブ先端に高低差をつけてマイクロリニアポ ンプに負荷をかける。その状態でマイクロリニアポンプを 各電圧, $2 \mathrm{~Hz}$ で 3 分間駆動し, 吐出された水の質量を量り 1 分間の吐出量を求める。この作業を 3 回繰り返して得られ たデータの平均值を図 12 に示している。

吐出口の圧力を $p_{o}[\mathrm{~Pa}]$, 吸入口の圧力を $p_{i}[\mathrm{~Pa}]$, 負荷圧力 を $p_{o}-p_{i}[\mathrm{~Pa}]$, 水の密度を $\rho\left[\mathrm{kg} / \mathrm{m}^{3}\right]$, 重力加速度を $g\left[\mathrm{~m} / \mathrm{s}^{2}\right]$, チューブ先端の高低差を $L[\mathrm{~m}]$ として

$$
P_{o}-P_{i}=\rho \times g \times L
$$


表 1 他社製マイクロポンプとの比較

Table 1. Data comparison of micro linear pumps with micro pump of other companies

\begin{tabular}{|c|c|c|c|c|}
\hline & Developed pump & A & B & $\mathrm{C}$ \\
\hline Maximum flow rate $[\mathrm{ml} / \mathrm{min}]$ & 1.2 & 1.5 & 2.4 & 8.33 \\
\hline Size $[\mathrm{mm}]$ & $\phi 6 \times 32.5$ & $23 \times 23 \times 4.7$ & $\begin{array}{c}\quad \phi 6.45 \times 7.9 \\
+ \text { external motor }\end{array}$ & $17.5 \times 26 \times 45$ \\
\hline $\begin{array}{c}\text { Maximum flow rate } \\
\text { Pump volume }\end{array}$ & 0.001 & 0.0006 & - & 0.004 \\
\hline Supply voltage & $2.0 \mathrm{Vp} \cdot \mathrm{p}$ & $300 \mathrm{Vp}-\mathrm{p}$ & $12 \mathrm{~V}$ & $230 \mathrm{~V}$ \\
\hline Power [W] & 0.4 & 0.06 & 5 & 5 \\
\hline Driving frequency $[\mathrm{Hz}]$ & 10 & 20 & 50 & 50 \\
\hline
\end{tabular}

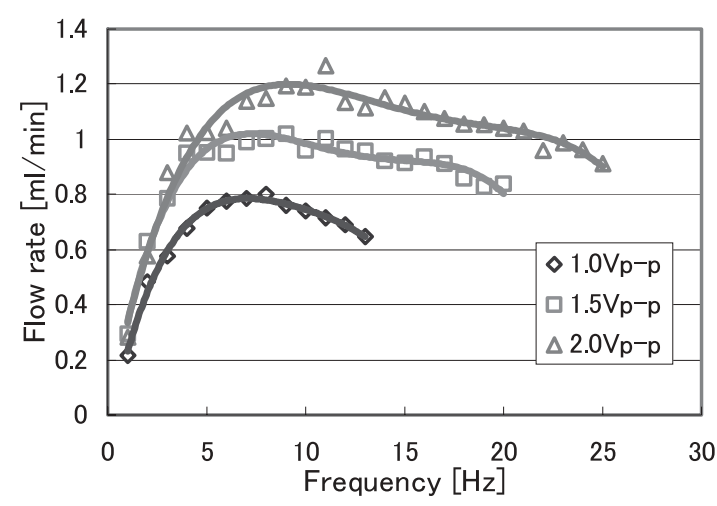

図 13 マイクロチェックバルブを改良後の周波数と吐 出量の関係

Fig. 13. Relation between frequency and flow rate after improvement of micro check-valve.

という関係式と測定時のチューブ先端の高低差から負荷圧 力は求められる。図 12 より負荷圧力が高くなるにつれて吐 出量は減少していき, 比較的に線形な関係であるという結 果が得られた。

\section{〈3.5〉 マイクロチェックバルブによる影響}

〜 〈3・4 では耐久性を考えて図 3 中の $\theta$ が $105^{\circ}$ のマイク ロチェックバルブを用いて試験を行なった。そこで， $\theta$ が $30^{\circ}$ の忘答性のよいマイクロチェックバルブを用いてコイ ルに印加する電圧の周波数と吐出量との関係を測定し，マ イクロチェックバルブがマイクロリニアポンプの特性にど れくらい影響しているのかを調べた。測定方法は〈3・2 と 同様である。測定により得られた結果を図 13 に示す。図 10 と図 13 を比較すると, 最大吐出量を約 $0.9 \mathrm{ml} / \mathrm{min}$ から約 $1.2 \mathrm{ml} / \mathrm{min}$ に増加させることに成功した。

\section{4. むすび}

電磁駆動を用いることにより, $\mathrm{ml} / \mathrm{min} レ$ レ゙のアクチュ エータ一体型マイクロリニアポンプの開発を行なった。測 定により, 最大吐出量約 $1.2 \mathrm{ml} / \mathrm{min}$ といら結果が得られた。 また, マイクロチェックバルブがマイクロリニアポンプの
特性に大きく影響を与えていることもわかった。

表 1 に今回開発したマイクロリニアポンプと従来の 3 つ のポンプの性能の比較を示す。A は圧電駆動のダイヤフラ ム式マイクロポンプ(3), B は外部から市販の電磁モータで駆 動するトロコイドポンプ(2), C は電磁駆動のポンプ(4)の特性 である。Bについては, 現在開発段階で大きなモータを用 いているために定量的な比較はできないが，外部モータま で考慮すると小型化は難しい。

以上のように, 比較的低電圧で動作し, 電磁アクチュエ ータと一体になった, 吐出量/ポンプ体積比の高いポンプが 実現できた。今後, チェックバルブの設計を詰めることに より,さらに性能の向上が期待できる。

(平成 17 年 3 月 24 日受付, 平成 17 年 5 月 30 日再受付)

\section{文献}

(1) T. Kitano, S. Shoji, Y. Baba, and H. Fujita : Technology and Application of Micro Chemical chip, MARUZEN CO., pp.271-280 (2004) (in Japanese)

北森武彦・庄子習一・馬場嘉信・藤田博之： $\mu$ 化学チップの技術と 応用, 丸善, pp.271-280 (2004)

(2) Y. Yamada : "Micro pump for $\mu \mathrm{TAS}$ ", Hydraulics \& Pneumatics, Vol.42, No.6, pp.12-16 (2003) (in Japanese) 山田嘉昭：「マイクロ TAS 用マイクロポンプ」, 油空圧技術, 42,6 , pp.12-16 (2003)

(3) STAR MICRONICS CO., LTD. : Diaphragm Micro Pump. スター精密株式会社 : ダイヤフラム式マイクロポンプ. http://www.star-m.jp/products/develop/de02.htm

(4) GOTEC : Electromagnetic pump GOTEC 社：電磁ポンプ. http://www.gotec.ch/index1.htm

鈴 森 康 - (正員) 1959 年 4 月 3 日生。1984 年横浜国立

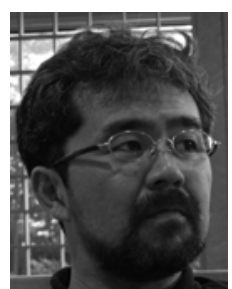
大学大学院工学研究科修士課程修了。同年(㑣東 芝入社。2001 年まで同社, 総合研究所および 研究開発センターに勤務。この間, 1990 年横 浜国立大学大学院工学研究科博士課程修了。 1999-2001 年財団法人マイクロマシンセンタ 一勤務。2001 年岡山大学教授, 現在に至る。 工学博士。各種アクチュエータの研究に従事。 日本機械学会, IEEE 等各会員。 


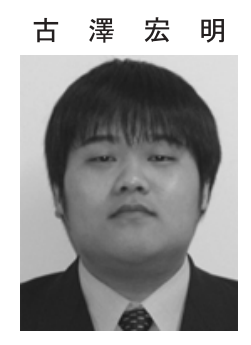

（非会員） 1982 年 11 月 26 日生。 2005 年 3 月岡山大学工学部システム工学科卒業。同年 4 月岡山大学大学院自然科学研究科博士前期課 程機械システム工学専攻進学, 現在に至る。主 にマイクロリアクターの関する研究に従事。日 本機械学会会員。

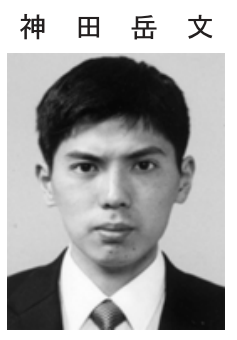

（正員） 1972 年 6 月 18 日生。 2002 年東京大 学大学院工学系研究科博士課程修了。同年 4 月 岡山大学大学院自然科学研究科助手, 2003 年 4 月岡山大学工学部講師, 現在に至る。博士（工 学)。主にマイクロセンサ, アクチュエータに 従事。精密工学会, IEEE, 日本機械学会, 日 本ロボット学会各会員。
山 田嘉 昭 (非会員) 1942 年 1 月 6 日生。 1965 年 3 月関

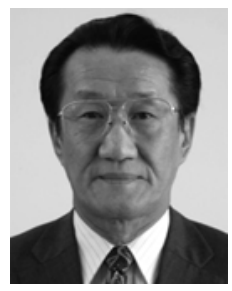
西大学工学部機械工学科卒業。同年 4 月(㑣化繊 ノズル製作所入社。1996 年 Kasen USA Corp. 社長就任。2002 年(㑣化繊ノズル製作所非常勤 顧問, 岡山県産業振興財団科学技術コーディネ 一夕，現在に至る。

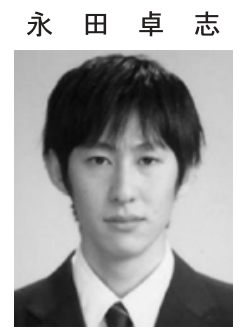

(非会員) 1980 年 10 月 3 日生。 2005 年 3 月 岡山大学大学院自然科学研究科博士前期課程 修了。同年 4 月㑣オリンパス入社, 現在に至る。 在学中, 主にマイクロリアクターに関寸る研究 に従事。日本機械学会, IEEE 各会員。 